\title{
BANK LENDING, EXPENDITURE COMPONENTS AND INFLATION IN SOUTH AFrica: ASSESSMENT FROM BOUNDS TESTING APPROACH
}

Emmanuel Ziramba

Department of Economics, University of South Africa

\begin{abstract}
This empirical study examines the long-run relationship between inflation and its determinants in South Africa. Three models of inflation involving money supply, bank credit and expenditure components are tested using the unrestricted error correction models of Pesaran et al. (2001). Unlike other existing studies on the subject, one of the models in the present study considers various components of real income as determinants. The disaggregated components are final consumption expenditure, expenditure on investment goods and exports. Based on "bounds" testing, the presence of a long-run equilibrium relationship between inflation and its determinants is confirmed for all three models. The study found that the major causes of inflation in South Africa are import prices, real income, and final consumption expenditure. The relationship is elastic for import prices and final consumption expenditure. Monetary variables, money supply and bank credit are found to have an indirect effect on inflation.
\end{abstract}

Abstract

JEL C22, E31, 51

\section{1}

\section{Introduction}

Inflation is considered to be one of the unresolved chronic problems facing many developing countries around the world (Dhakil \& Kandil, 1993). Various explanations have been advanced in the theoretical literature. The causes of inflation can be broadly classified in two categories: demand-pull and cost-push inflation. Demand-pull inflation derives from excess demand in the economy and is related to total expenditure and the level of money supply. Cost-push inflation is related to rising costs in production. These causes of inflation can arise within the economy or from external sources.

Strydom (1976) argued that inflation could not be attributed to a single factor. It has to be assessed in terms of the entire macro-economic system. This calls for the analysis of aggregate demand pressures; the relationship between aggregate demand and the money supply; and aggregate supply aspects that relate to the price and wage equations.

The Commission of Inquiry into the Monetary System and Monetary Policy in South Africa (the De Kock Commission) believes that the excessive and highly unstable growth of the monetary aggregates was a prime element in both a causal and permissive sense in accounting for the inflationary experience from the 1960s to the 1980s (Mohr, 1986). Although South Africa's targeted measure of inflation, CPIX, remained within the inflation target range of 3-6 per cent, the inflation rate rose towards the end of 2006. The CPIX inflation rate was 3.8 per cent in March 2006 and went up to 5.1 per cent in September 2006 (South African Reserve Bank, 2006). Its evolution was attributed mainly to developments in food and energy prices, as shown in Table 1. 


\section{Table 1}

Contributions to CPIX inflation (percentage change over twelve months* and percentage points)

\begin{tabular}{|c|c|c|c|c|c|c|c|}
\hline & \multicolumn{7}{|c|}{2007} \\
\hline & Mar & Apr & May & Jun & Jul & Aug & Sep \\
\hline Total* & 5.5 & 6.3 & 6.4 & 6.4 & 6.5 & 6.3 & 6.7 \\
\hline \multicolumn{8}{|l|}{ Of which } \\
\hline Food & 2.1 & 2.3 & 2.4 & 2.5 & 2.7 & 3.0 & 3.2 \\
\hline Housing & 0.6 & 0.7 & 0.7 & 0.7 & 0.9 & 0.8 & 0.8 \\
\hline $\begin{array}{l}\text { Medical care \& health } \\
\text { expenses }\end{array}$ & 0.5 & 0.5 & 0.5 & 0.5 & 0.5 & 0.5 & 0.5 \\
\hline Household operation & 0.4 & 0.5 & 0.5 & 0.4 & 0.4 & 0.4 & 0.4 \\
\hline Transport & 0.7 & 1.1 & 1.1 & 1.0 & 0.6 & 0.2 & 0.4 \\
\hline Education & 0.4 & 0.4 & 0.4 & 0.4 & 0.4 & 0.4 & 0.4 \\
\hline Clothing and footwear & -0.2 & -0.2 & -0.2 & -0.2 & -0.2 & -0.2 & -0.2 \\
\hline Fuel and power & 0.3 & 0.3 & 0.3 & 0.3 & 0.4 & 0.4 & 0.3 \\
\hline Other & 0.7 & 0.7 & 0.7 & 0.8 & 0.8 & 0.8 & 0.9 \\
\hline
\end{tabular}

Source: South African Reserve Bank, Monetary Policy Review, November 2007, p. 3.

At its April 2006 meeting, the Monetary Policy Committee (MPC) of the South African Reserve Bank identified and warned on a number of inflation outlook risk factors. The strong rate of growth of household real consumption expenditure was underlined. Consumer demand has continued to increase, which as reflected in both the growth rate of credit extension in excess of 27 per cent, and rising household indebtedness, which had risen to 68 per cent of annualised household disposable income (South African Reserve Bank, 2006: 19). Table 2 below shows the growth rates in the expenditure components in the past few quarters. It can be seen that on average they all increased at rates far in excess of the upper inflation target. Monetary authorities have blamed the continued increase in consumer demand on indiscriminate lending by banks. The new National Credit Act number 34 of 2005, which became effective from 1 June 2007, seeks to address this problem.

Table 2

Growth in real gross domestic product and expenditure components (per cent)

\begin{tabular}{|l|c|c|c|c|c|}
\hline & \multicolumn{3}{|c|}{$\mathbf{2 0 0 6}$} & \multicolumn{2}{c|}{$\mathbf{2 0 0 7}$} \\
\cline { 2 - 6 } & $\mathbf{2}^{\text {nd }} \mathbf{q r}$ & $\mathbf{3}^{\text {rd }} \mathbf{q r}$ & $\mathbf{4}^{\text {th }} \mathbf{q r}$ & $\mathbf{1}^{\text {st }} \mathbf{q r}$ & $\mathbf{2}^{\text {nd }} \mathbf{q r}$ \\
\hline Final consumption expenditure: & & & & & \\
\hline Households ... & 8.1 & 7.6 & 7.8 & 7.4 & 5.5 \\
\hline Government ... & 15.7 & -4.4 & 4.7 & 13.9 & -3.1 \\
\hline Gross fixed capital formation ... & 12.8 & 14.0 & 16.4 & 21.8 & 14.2 \\
\hline Change in inventories (R billions) ... & 16.3 & 9.0 & 21.8 & 11.8 & 10.5 \\
\hline Gross domestic expenditure ... & $\mathbf{9 . 0}$ & $\mathbf{1 . 4}$ & $\mathbf{1 2 . 3}$ & $\mathbf{5 . 8}$ & $\mathbf{1 . 1}$ \\
\hline
\end{tabular}




\begin{tabular}{|l|c|c|c|c|c|}
\hline Exports of goods and services ... & 24.9 & 19.4 & 39.7 & -11.2 & 4.0 \\
\hline Imports of goods and services ... & 34.4 & 5.5 & 58.3 & -5.0 & -5.8 \\
\hline Gross domestic product ... & $\mathbf{5 . 5}$ & $\mathbf{4 . 5}$ & $\mathbf{5 . 6}$ & $\mathbf{4 . 7}$ & $\mathbf{4 . 5}$ \\
\hline
\end{tabular}

Source: South African Reserve Bank, Monetary Policy Review, November 2007, p.16.

2

\section{The evolution of South Africa's monetary policy}

Monetary policy has been defined as the measures taken by monetary authorities to influence the quantity of money or the rate of interest with a view to achieving stable prices, full employment and economic growth (Mohr et al., 2007: 329). The monetary policy framework in South Africa has undergone numerous changes in the country's history. According to Mohr et al. (2007: 330-31), South Africa's monetary policy framework has gone through five regimes since the 1960s: a liquid asset-based system, a mixed system, a cost of cash reserves-based system with monetary targeting, a repurchase agreement (repo) system with monetary targeting and informal inflation targeting, and a repo system with formal inflation targeting. These regimes are summarised in Table 3.

\section{Table 3}

Evolution of South Africa's monetary policy framework

\begin{tabular}{|c|l|}
\hline Years & \multicolumn{1}{|c|}{ Monetary policy framework } \\
\hline $1960-1981$ & Liquid asset ratio-based system with quantitative controls over interest rates and credit \\
\hline $1981-1985$ & Mixed system during transition period \\
\hline $1986-1998$ & Cost of cash reserves-based system with pre-announced guidelines for growth in (M3) \\
\hline $1998-1999$ & $\begin{array}{l}\text { Daily tenders of liquidity through repurchase transactions (repo system), plus pre-announced } \\
\text { M3 targets and informal targets for core inflation }\end{array}$ \\
\hline $2000-$ & Formal inflation targeting \\
\hline
\end{tabular}

Source: Mohr et al. (2007: 331)

\section{3}

\section{Bank lending channel transmission mechanism}

The transmission mechanism describes the link between monetary policy actions and their impact on real economic activity and inflation. Several interrelated transmission channels may be at work (Mishkin, 1995).The focus here is on the bank-lending channel, which attributes the effects of monetary policy to movements in the supply of bank credit. Kashyap and Stein (1993) argue that, according to the lending view of monetary transmission, there are three assets: money, publicly-issued bonds and intermediated loans. In this view, banks play two roles. They create money and make loans, which the household sector cannot perform. In this threeasset world, monetary policy affects investment not only through interest rates but also in its impact on the supply of bank loans.

This means that certain borrowers do not have access to credit markets unless they borrow from banks. Contractionary monetary policy decreases bank reserves and bank deposits, thereby reducing the number of loans available. This decrease in loans will cause investment and consumer spending to fall. This channel can be represented as follows:

$\uparrow$ repo $\rightarrow \downarrow$ bank deposits $\rightarrow \downarrow$ bank loans $\rightarrow \downarrow$ I, $\downarrow \mathrm{C} \rightarrow \downarrow \mathrm{y}$ 
The evidence concerning the empirical relationship between monetary policy, bank loans and economic activity in South Africa is mixed (Smal \& de Jager, 2001; Sichei, 2005; Ludi \& Ground, 2006). Smal and de Jager (2001) realised that there are fairly lengthy time lags of approximately one year before a change in monetary policy affects the level of real activity, and another year before it affects the domestic price level. Sichei (2005), using dynamic panel estimation methods, showed that the banklending channel operates in South Africa. Ludi and Ground (2006), using structural vector error autoregressions, found that loans in South Africa are governed by consumer demand. Their results do not support the bank-lending channel in South Africa.

This paper empirically investigates the extent to which bank lending and expenditure components contributed to the inflation process in South Africa over the annual period 1970 2005. The monetary influence on prices works mainly through the effects of money on demand. We therefore include a model that incorporates expenditure components in our analysis in order to capture all monetary effects.

The structure of the paper is as follows. Section 2 provides a discussion of empirical studies on the subject. The model, data and method are presented in section 3. Empirical results are presented in section 4 . The conclusion and policy implications are presented in section 5 .

\section{4 \\ Empirical literature review}

There is extensive empirical literature on inflation and bank lending in South Africa and other developing countries. Anoruo (2003) ascertains the time series properties of budget deficits, inflation and M3 using a VECM model. He finds that real broad money supply Grangercauses inflation, and that there is a bi-directional causal relationship between real budget deficits and inflation. Using VAR and VECM models, Kaseeram et al. (2004) estimate the relationship between inflation and excess demand, labour costs, import prices and exchange rates, with special attention to the pass-through effects from devaluation to unit labour costs. They find that exchange rate depreciation increases inflation through labour union-induced wage increases. Further, they find evidence of a significant degree of inflation persistence, indicating that inertia or inflationary expectations play a major role in the inflationary process.

Fedderke and Schaling (2005), using multivariate co-integration techniques, investigated the link between inflation, unit labour costs, the output gap, the real exchange rate and inflation expectations. They provided evidence consistent with a cost-push view of the inflationary process in South Africa, for example, that prices are set as a mark-up over productivity-adjusted labour costs.

Nell (2000) investigated the inflationary impact of exchange rate depreciation in South Africa over the period 1973-1998. His empirical results show that the long-run causes of inflation in South Africa have changed from demand-pull inflation over the period 1973-1983 to cost-push causes (import prices and wage rate changes) of inflation since 1987, when a market-determined exchange rate finally stabilised.

Dhakal and Kandil (1993) investigated the major determinants of the inflation rate in six developing Asian countries: Bangladesh, India, Malaysia, Pakistan, Singapore and South Korea. Their results show that the growth of the money stock was not a primary source of inflation in all countries but that the various factors influencing the public's willingness to hold money were behind inflationary pressure across countries. These factors included foreign interest rates and import prices. The researchers concluded that the success of domestic policy in fighting inflation was highly dependent on the unique inflationary experience of each country.

Tang (2001) estimated inflation models for Malaysia using unrestricted error-correction models (UECMs) proposed by Pesaran et al. (2001). The sample period covered was 19731997. The results of "bounds" tests confirmed a long-run equilibrium relationship between inflation and its determinants, namely import price, money supply (M3), bank credit and real income. The estimated UECMs revealed the important factors in the Malaysian inflation process to be import price and real income variables. 


\section{5}

\section{Model specification and method}

The empirical literature has provided the basis for inflation specification in this study. The inclusion of bank credit was first introduced by Tang (2001). The introduction of expenditure components as separate determinants in the inflation model is a significant departure from that found in previous studies. Data used for analysis covers the annual period 1970-2005 (36 observations). Quarterly or monthly data are unavailable for most components of final demand for a substantially long period. Given the small sample size, the co-integration relationship among the variables in the inflation models is analysed by means of the bounds test proposed by Pesaran et al. (2001).

Thus, the long-run inflation equations can be specified as:

$$
\begin{aligned}
& \operatorname{lnCPI}_{\mathrm{t}}=\delta_{0}+\delta_{1} \ln P M_{t}+\delta_{2} \ln M 3_{t}+\delta_{3} \ln Y_{t}+u_{t} \\
& \operatorname{lnCPI}=y_{0}+y_{1} \ln P M_{t}+y_{2} \ln B C_{t}+y_{3} \ln Y_{t}+u_{t} \\
& \operatorname{lnCPI}_{\mathrm{t}}=\beta_{0}+\beta_{1} \ln P M_{t}+\beta_{2} \ln E X_{t}+\beta_{3} \ln E I G_{t}+\beta_{4} \ln F C E_{t}+u_{t}
\end{aligned}
$$

From economic theory the coefficients $\delta_{1}, \delta_{2}$, $\delta_{3}, y_{1}, y_{2}, y_{3}, \beta_{1}, \beta_{2}, \beta_{3}$ and $\beta_{4}$ are expected to be positive.
The bounds test starts from the estimation of unrestricted error correction models (UECMs) of the form

$$
\begin{aligned}
\Delta \ln C P I_{t}= & \alpha_{0}+\sum_{i=0}^{n} \alpha_{1 i} \Delta \ln P M_{t-i}+\sum_{i=0}^{n} \alpha_{2 i} \Delta \ln M 3_{t-i}+\sum_{i=0}^{n} \alpha_{3 i} \Delta \ln Y_{t-i}+\sum_{i=1}^{n} \alpha_{4 i} \Delta \ln C P I_{t-i} \\
& +\alpha_{5} \ln C P I_{t-1}+\alpha_{6} \ln P M_{t-1}+\alpha_{7} \ln M 3_{t-1}+\alpha_{8} \ln Y_{t-1}+e_{t} \\
\Delta \ln C P I_{t}= & \sigma_{0}+\sum_{i=0}^{n} \sigma_{1 i} \Delta \ln P M_{t-i}+\sum_{i=0}^{n} \sigma_{2 i} \Delta \ln B C_{t-i}+\sum_{i=0}^{n} \sigma_{3 i} \Delta \ln Y_{t-i}+\sum_{i=1}^{n} \sigma_{4 i} \Delta \ln C P I_{t-i} \\
& +\sigma_{5} \ln C P I_{t-1}+\sigma_{6} \ln P M_{t-1}+\sigma_{7} \ln B C_{t-1}+\sigma_{8} \ln Y_{t-1}+u_{t} \\
\Delta \ln C P I_{t}= & \theta_{0}+\sum_{i=0}^{n} \theta_{1 i} \Delta \ln P M_{t-i}+\sum_{i=0}^{n} \theta_{2 i} \Delta \ln E X_{t-i}+\sum_{i=0}^{n} \theta_{3 i} \Delta \ln E I G_{t-i}+\sum_{i=0}^{n} \theta_{4 i} \Delta \ln F C E_{t-i} \\
& +\sum_{i=1}^{n} \theta_{5 i} \Delta \ln C P I_{t-i}+\theta_{6} \ln C P I_{t-1}+\theta_{7} \ln P M_{t-1}+\theta_{8} \ln E X_{t-1}+\theta_{9} \ln E I G_{t-1} \\
& +\theta_{10} \ln F C E_{t-1}+\varepsilon_{t}
\end{aligned}
$$

where $\Delta \operatorname{lnCPI}, \Delta \ln \mathrm{PM}, \Delta \ln \mathrm{M} 3, \Delta \ln B C$ and $\Delta \ln Y$ are first differences of the logarithms of consumer price index, import price index, money supply, bank credit and real GDP respectively.

Equation (6) is model 3, which disaggregates real income into three components in order to assess their individual effects on inflation. The disaggregated components are final consumption expenditure, expenditure on investment goods and exports. This approach was adopted from Giovannetti (1989).

Pesaran et al. (2001) have established that, under the null hypothesis of no co-integration, and regardless of the degree of integration of the variables, the asymptotic distribution of the obtained F-statistic is non-standard. They develop two bounds of critical values for the different model specifications: the upper bound applies when all variables are I (1) while the lower bound applies when all the variables are I (0). If the computed F-statistic for a chosen level of significance exceeds the upper bound, the null hypothesis of no co-integration is rejected. If the F-statistic is lower than the lower bound then the null hypothesis cannot be rejected. If the F-statistic lies between the lower and the upper bounds, conclusive inference cannot be made. 
Hendry's 'general to specific' approach (Hendry et al., 1984) was used in this study to obtain preferred UECMs in order to address the issues of over-parameterisation and save the degrees of freedom. First the researchers introduced a relatively long lag length in the model. Next they gradually dropped statistically insignificant variables in order to end up with parsimonious models. Specification and diagnostic tests are presented to assess the appropriateness of the selected parsimonious model.

From the estimated UECM, the long-run elasticities are the coefficient of the one-lagged explanatory variables (multiplied by a negative sign) divided by the coefficient of the onelagged dependent variable (Bardsen, 1989). The long-run import price, money supply and income elasticities are $-(\alpha 6 / \alpha 5),-(\alpha 7 / \alpha 5)$ and $-(\alpha 8 / \alpha 5)$ respectively. The short-run effects are captured by the coefficients of the first-differenced variables in equation (4). The steps are exactly the same for equations (5) and (6).

\section{6}

\section{Empirical results}

The estimation of UECM for equations (4) and (5) are reported in Tables 3 and 4 respectively. Table 3 reports the estimation results of equation (4). The import price is found to be significant in both the short and long run. In the short run it is significant up to the second lag. The money supply M3 is found to be insignificant in the long run but significant in the short run. The real income is found to be significant in both the long and short run. The long-run import price, money supply and income elasticities are 1.75, 0.79 and -5.82 respectively. The presence of a long-run equilibrium relationship between inflation and its determinants in equation (1) is tested using the bounds testing approach by Pesaran et al. (2001). The test statistic (F-statistic) is 5.8, which is found to exceed the upper bounds value I(1) of 5.61 for one per cent significance level. The lower bounds value is $4.29, \mathrm{I}(0)$. The upper and lower bounds values are obtained from Pesaran et al. (2001: 300), Table CI(iii) case III: unrestricted intercept and no trend, with three regressors case $(\mathrm{k}=3)$. Thus, the null hypothesis of no co-integration relationship can be rejected. This result indicates that inflation, import prices, money supply and real income are co-integrated. The presence of a co-integrating relationship indicates that the CPI inflation model used in this study is specified correctly and that it is stable over the sample period. All the determinants are found inelastic in the short run. The short-run M3 variable is significant but the elasticity is -0.239 , which runs contrary to economic theory. Tang (2001) found a similar result in the case of Malaysia, and suggested that money supply in the narrow sense has indirect effects on inflation, imposing its most significant effect through the exchange-rate channel. Consequently, the negative sign did not have a direct effect on inflation.

Table 4 shows the estimation results of equation (5). Bank credit was found insignificant in the long run but significant in the short run. Import price and real income are significant at 5 and 10 per cent levels respectively. The presence of a long-run relationship in equation (5) was also investigated using the 'bounds' testing approach (Pesaran et al., 2001). Table 6 shows that the computed F-statistic (Model 2 , Table 4) is 3.41 , which exceeds the critical upper bound of 3.10 at 10 per cent level, Table CI(i) case I: no intercept and no trend, with three regressors case $(\mathrm{k}=3)$. The null hypothesis of no co-integration relationship can thus be rejected. 


\section{Table 4}

Estimation of UECM with M3 (dependent variable $\triangle \mathrm{lnCPI}$ )

\begin{tabular}{|l|c|c|c|}
\hline \multicolumn{1}{|c|}{ Variable } & Coefficient & t-Statistic & Prob \\
\hline$\Delta \operatorname{lnPM}$ & 0.122462 & 2.725834 & 0.0127 \\
\hline$\Delta \operatorname{lnPM}(\mathrm{t}-1)$ & -0.148260 & -2.437258 & 0.0238 \\
\hline$\Delta \operatorname{lnPM}(\mathrm{t}-2)$ & -0.170178 & -3.621054 & 0.0016 \\
\hline$\Delta \operatorname{lnM} 3$ & -0.238678 & -3.717445 & 0.0013 \\
\hline$\Delta \operatorname{lnY}(\mathrm{t}-1)$ & 0.534999 & 2.875426 & 0.0091 \\
\hline$\Delta \operatorname{lnY}(\mathrm{t}-2)$ & 0.332040 & 1.905981 & 0.0704 \\
\hline$\Delta \operatorname{lnCPI}(\mathrm{t}-1)$ & 0.482608 & 3.565292 & 0.0018 \\
\hline $\operatorname{InCPI}(\mathrm{t}-1)$ & -0.138536 & -4.328941 & 0.0003 \\
\hline $\ln \mathrm{PM}(\mathrm{t}-1)$ & 0.242514 & 4.148723 & 0.0005 \\
\hline LnM3(t-1) & 0.109941 & 1.555314 & 0.1348 \\
\hline $\operatorname{InY}(\mathrm{t}-1)$ & -0.806086 & -3.021707 & 0.0065 \\
\hline Constant & 9.696507 & 3.207581 & 0.0042 \\
\hline Adjusted R & 0.880087 & & \\
\hline F-Statistic & 22.35086 & & \\
\hline DW & 2.272066 & & \\
\hline
\end{tabular}

Ramsey RESET test (2)

Jarque-Bera test

White's test

Breusch-Godrey LM test

ARCH test (2)
F-statistic : 0.11(0.9)

JB : 2.22(0.33)

F-statistic : 059(0.86)

F-statistic : 2.18(0.14)

F-statistic : 0.61(0.55)

Number in parentheses indicates p-value.

\section{Figure 1}

Plots of Cusum and Cusum of Squares for M3
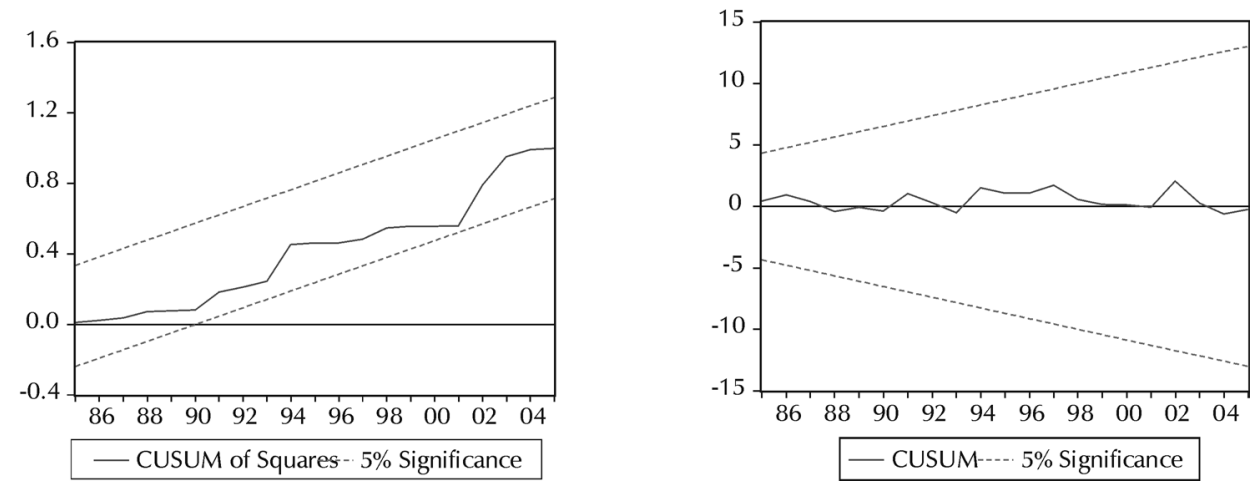


\section{Table 5}

Estimation of UECM with bank credit (dependent variable $\Delta \mathrm{lnCPI})$

\begin{tabular}{|l|c|c|c|}
\hline \multicolumn{1}{|c|}{ Variable } & Coefficient & t-Statistic & Prob \\
\hline$\Delta \operatorname{lnPM}$ & 0.108111 & 2.086259 & 0.0473 \\
\hline$\Delta \operatorname{lnPM}(\mathrm{t}-2)$ & -0.096666 & -1.996488 & 0.0569 \\
\hline$\Delta \operatorname{lnBC}$ & -0.223316 & -3.294365 & 0.0029 \\
\hline$\Delta \operatorname{lnCPI}(\mathrm{t}-1)$ & 0.406816 & 2.419582 & 0.0231 \\
\hline $\operatorname{InCPI}(\mathrm{t}-1)$ & -0.062768 & -2.605427 & 0.0152 \\
\hline $\operatorname{InPM}(\mathrm{t}-1)$ & 0.063976 & 2.374023 & 0.0256 \\
\hline $\ln \mathrm{BC}(\mathrm{t}-1)$ & -0.084790 & -1.705185 & 0.1006 \\
\hline $\operatorname{InY}(\mathrm{t}-1)$ & 0.057213 & 1.873057 & 0.0728 \\
\hline Adjusted $\mathrm{R}^{2}$ & 0.838120 & & \\
\hline DW & 1.585676 & & \\
\hline
\end{tabular}

\section{Ramsey RESET test (2)}

Jarque-Bera test

White's test

Breusch-Godrey LM test

ARCH test (2)
F-statistic : $0.23(0.80)$

JB : 1.24(0.54)

F-statistic : $0.53(0.89)$

F-statistic : $1.18(0.32)$

F-statistic : $0.16(0.85)$

Number in parentheses indicates p-value.

\section{Figure 2}

Plots of Cusum and Cusum of Squares for bank credit

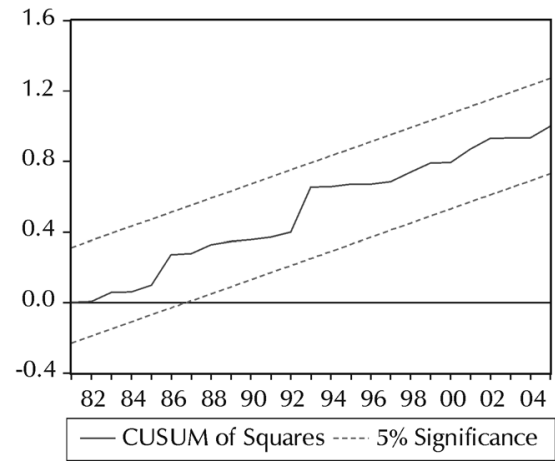

Table 5 shows the estimation results of equation (6). As in models 1 and 2, the import price is found significant in both the long and short run. All the expenditure components are found significant in the long run. In the short run, only exports expenditure is significant. Table 6 shows that the computed F-statistic (Model 3, Table 5) is 51.4, which exceeds the upper "bounds" value

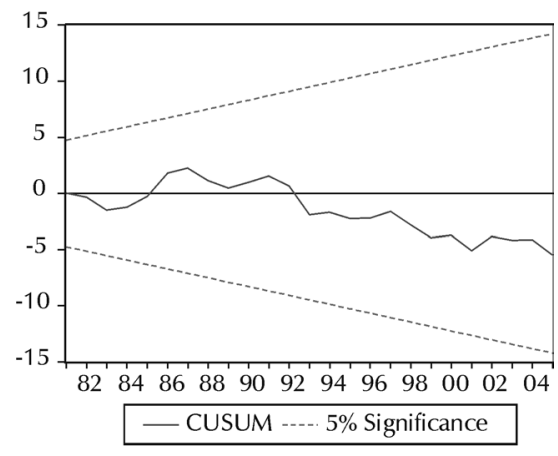

(4.44), Table CI(i) Case I: no intercept and no trend, with four regressors case $(\mathrm{k}=4)$ at 1 per cent level, rejecting the null hypothesis of no co-integration relationship. All the expenditure components are found inelastic in the short-run. The long run elasticities for exports, investment expenditure and final consumption expenditure are $-0.61,-1.45$ and 1.96 . 


\section{Table 6}

Estimation of UECM with expenditure components (dependent variable $\Delta \mathrm{lnCPI}$ )

\begin{tabular}{|l|c|c|c|}
\hline \multicolumn{1}{|c|}{ Variable } & Coefficient & t-Statistic & Prob. \\
\hline$\Delta$ LNPM & 0.180283 & 4.433088 & 0.0002 \\
\hline$\Delta$ LNEX & -0.325637 & -4.003620 & 0.0005 \\
\hline$\Delta$ LNFCE & -0.192158 & -0.893829 & 0.3796 \\
\hline$\Delta$ LNEIG & -0.054830 & -0.852260 & 0.4019 \\
\hline LNCPI(t-1) & -0.135527 & -4.946413 & 0.0000 \\
\hline LNPM(t-1) & 0.099766 & 3.977120 & 0.0005 \\
\hline LNEIG(t-1) & -0.197113 & -6.471492 & 0.0000 \\
\hline LNEX(t-1) & -0.082849 & -2.834932 & 0.0088 \\
\hline LNFCE(t-1) & 0.266294 & 9.345609 & 0.0000 \\
\hline Adjusted R & 0.867195 & & \\
\hline DW & 1.729935 & & \\
\hline
\end{tabular}

Ramsey RESET test (2)

Jarque-Bera test

White's test

Breusch-Godrey LM test

ARCH test (2)
F-statistic : $0.795(0.46)$

JB : $0.39(0.82)$

F-statistic : $0.586(0.86)$

F-statistic : $1.30(0.29)$

F-statistic : $0.455(0.64)$

Figure 3

Plots of Cusum and Cusum of Squares for expenditure components

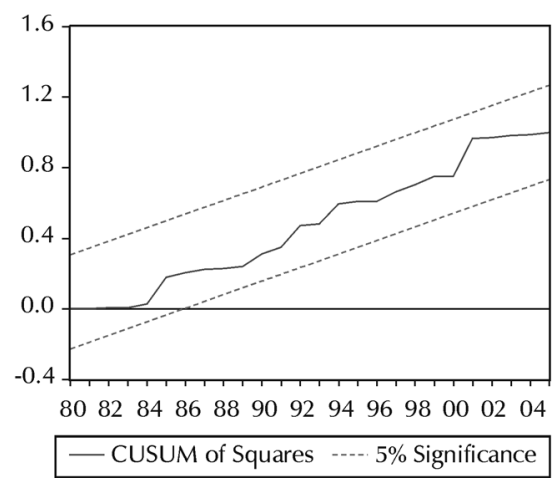

The adjusted $\mathrm{R}^{2}$ of the estimated UECMs is reasonably high at 88,84 and 87 per cent for model 1, 2 and 3 respectively. The final UECMs pass a battery of diagnostic tests, which are reported in Tables 3, 4 and 5. The Jarque-Bera statistic confirms the normality of the residuals.

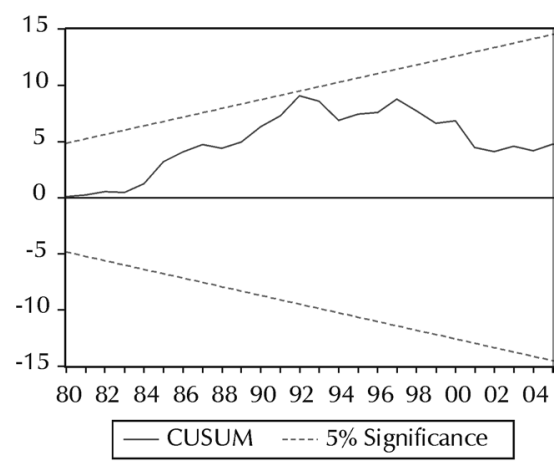

The Breusch-Godfrey LM test rejects the presence of serial correlation. The ARCH test rejects first and second orders heteroscedasticity in the disturbance terms. White's test also rejects the presence of heteroscedasticity in the residuals. The Ramsey reset indicates that 
there are no general specification errors in either model. Finally, the plots of CUSUM and CUSUM of squares (figures 1, 2 and 3) reveal that the estimated parameters are stable over the sample period. The UECMs appear to fit the data well and to be suitable for forecasting.

\section{Table 7}

Bounds testing for co-integration analysis

\begin{tabular}{|l|c|c|c|}
\hline \multicolumn{1}{|c|}{ Model } & \multirow{2}{*}{$\begin{array}{c}\text { Computed } \\
\text { F-statistic }\end{array}$} & \multicolumn{2}{c|}{ Critical bounds at 1\% (a), 10\%(b) } \\
\cline { 3 - 4 } & & Lower bound I(0) & Upper bound I(1) \\
\hline Model 1 Table 1: with M3 & 5.80 & $4.29^{\mathrm{a}}$ & 5.61 \\
\hline Model 2 Table 2: with Bank Credit & 3.41 & $2.01^{\mathrm{b}}$ & 3.10 \\
\hline Model 3 with Expenditure components & 51.4 & $3.07^{\mathrm{a}}$ & 4.44 \\
\hline
\end{tabular}

Critical values come from Pesaran et al., 2001, p.300, model 1, Cl (iii), models 2 and 3, Cl (i).

7

\section{Conclusions and policy implications}

The present study estimated inflation models for South Africa over the period 1970-2005. It employed the UECMs approach of Pesaran et al. (2001) to estimate long-run and shortrun effects of import price, money supply, bank credit, real income and expenditure components on inflation. The results of "bounds" testing confirm the presence of a long-run equilibrium relationship between inflation and its determinants for all our models. The introduction of expenditure components in the analysis of inflationary dynamics in South Africa is a significant departure from previous studies and contribution of this study.

The study found that the major causes of inflation in South Africa are import prices, real income, and final consumption expenditure, and that the relationship is elastic for import prices and final consumption expenditure. Monetary variables, money supply and bank credit are found to be insignificant but the existence of a co-integrating relationship reveals an indirect effect on inflation. The estimated long-run elasticities for import prices, money supply, real income, bank credit, exports, and investment expenditure and final consumption expenditure are $1.75 ; 0.79 ; 0.91 ;-1.35 ;-0.61 ;-1.45$ and 1.96 respectively. An increase in final consumption expenditure will elastically increase inflation in South Africa. Domestic demand should therefore be kept in check, particularly at the disaggregate level. Inflation was found to increase elastically with import prices. This calls for monitoring on import expenditures, especially on luxury items. The findings have some profound implications for fiscal policies in curbing inflationary pressures, as they offer an alternative to monetary policy with direct effects on inflation. Finally, the unrestricted errorcorrection models appear to be an appropriate framework for forecasting inflation behaviour in South Africa.

\section{References}

1 ANORUO, E.C. (2003) "An empirical investigation into the budget deficit-inflation nexus in South Africa", South African Journal of Economics, 71(2): 282-297.

2 BARDSEN, G. (1989) "Estimation of long-run coefficients in error correction models", Oxford Bulletin of Economics and Statistics, 51(3): 345-50.

3 CASTELEIJN, A.J.H. (2001) "South Africa's monetary policy framework", South African Reserve Bank Conference paper, 17-19 September, 2001.

4 DHAKAL, D. \& KANDIL, M. (1993) "The inflationary experiences of six developing countries in Asia: An investigation of underlying determinants", Applied Economics, 25: 413- 425.

5 FEDDERKE, J.W. \& SCHALING, E. (2005) "Modeling inflation in South Africa: A multivariate cointegration analysis", South African Journal of Economics, 73(1): 79-92.

6 GIOVANNETTI, G. (1989) "Aggregate imports and expenditure components in Italy: An econometric analysis", Applied Economics, 21, 957971. 
7 HENDRY, D.F.; PAGAN, A. \& SARGAN, J.D. (1984) "Dynamic specification", in Z. Griliches \& M. Intrilligator (eds) Handbook of Econometrics 2, North Holland: Amsterdam.

8 KASEERAM, I.; NICOLA, T. \& MAINARDI, S. (2004) "South African inflationary dynamics and the pass-through effect from depreciation to unit labour costs", South African Journal of Economics, 72(1): 85-107.

9. KASHYAP, A.K. \& STEIN, J.C. (1993) Monetary policy and bank lending, NBER Working Paper series, No 4317.

10 LUDI, K.L. \& GROUND, M. (2006)

"Investigating the bank-lending channel in South Africa: A VAR approach", University of Pretoria, working paper: 2006-04.

11 MISHKIN, F.S. (1995) Symposium on the monetary transmission mechanism, Journal of Economic Perspectives, 9(4) 3-10.

12 MOHR, P.J. (1986) "The de Kock Commission and inflation", South African Journal of Economics, 54(1): 22-39.

13 MOHR, P.J.; FOURIE, L. \& ASSOCIATES (2007) Economics for South African Students ( $4^{\text {th }}$ ed.) Van Schaik Publishers: Pretoria.
14 NELL, K.S. (2000) "Imported inflation in South Africa: An empirical study”, University of Kent: Studies in Economics Series.

15 PESARAN, M.H., SHIN, Y. \& SMITH, R.J. (2001) "Bounds testing approaches to the analysis of level relationships", Journal of Applied Econometrics 16(3): 289-326.

16 SICHEI, M. (2005) Bank-lending channel in South Africa: bank-level dynamic panel data analysis. University of Pretoria, working paper: 2005-10.

17 SMAL, M.M. \& DE JAGER, S. (2001) "The monetary transmission mechanism in South Africa”, South African Reserve Bank Occasional Paper No. 16.

18 SOUTH AFRICAN RESERVE BANK (2006) Monetary Policy Review, November 2006.

19 STRYDOM, P.D.F. (1976) "Inflation in South Africa I: Institutional Aspects", South African Journal of Economics, 44(2): 115-138.

20 TANG, T.C. (2001) "Bank-lending and inflation in Malaysia: Assessment from unrestricted errorcorrection models", Asian Economics Journal, 15(3): 275-289. 


\section{APPENDIX: DATA DEFINITIONS AND SOURCES}

The data covered the available annual period 1970 to 2005. The raw data was obtained from the South African Reserve Bank, (www.reservebank.co.za). All series are in natural logarithmic form (ln). The definitions of the involved variables are given below:

1. RM1=narrow money supply in real terms. Nominal value of M1 deflated by the consumer price index $(2000=100)$.

2. $\mathrm{RM} 2=$ money supply in real terms. Nominal value of $\mathrm{M} 2$ deflated by the consumer price index $(2000=100)$.

3. $\mathrm{RM} 3$ = broad money supply in real terms. Nominal value of M3 deflated by the consumer price index $(2000=100)$.

4. $\quad$ EIG $=$ Expenditure on investment goods is gross fixed capital formation at constant prices (in R millions) $(2000=100)$;

5. $\quad \mathrm{EXP}=$ Exports of goods and non-factor services (in R millions) $(2000=100)$;

6. $\mathrm{FCE}=$ Final consumption expenditure. It is the sum of household consumption and general government consumption (in R millions). 